\title{
First genome size estimations for some eudicot families and genera
}

\author{
S. GARCIA ${ }^{1}$, T. GARNATJE ${ }^{1}$, O. HIDALGO², G. MAS DE XAXARS ${ }^{3}$, \\ J. PELLICER ${ }^{4}$, I. SÁNCHEZ-JIMÉNEZ ${ }^{1}$, D. VITALES ${ }^{3} \&$ J. VALLÈS ${ }^{3}$ \\ ${ }^{1}$ Institut Botànic de Barcelona (CSIC-ICUB), Psg. del Migdia s/n., 08038 Barcelona, Catalonia, Spain \\ ${ }^{2}$ Department of Environmental and Plant Biology, Ohio University, Porter Hall 500, Athens, OH 45701, USA \\ ${ }^{3}$ Laboratori de Botànica, Facultat de Farmàcia, Universitat de Barcelona, Av. Joan XXIII s/n., 08028 Barcelona, \\ Catalonia, Spain \\ ${ }^{4}$ Jodrell Laboratory, Royal Botanic Gardens, Kew, Richmond, Surrey TW9 3AB, United Kingdom
}

Author for correspondence: S. Garcia (soniagarcia@ibb.csic.es)

Received 1 October 2010; Accepted 9 November 2010

\begin{abstract}
First genome size estimations for some eudicot families and genera.- Genome size diversity in angiosperms varies roughly 2400 -fold, although approximately $45 \%$ of angiosperm families lack a single genome size estimation, and therefore, this range could be enlarged. To contribute completing family and genera representation, DNA C-Values are here provided for 19 species from 16 eudicot families, including first values for 6 families, 14 genera and 17 species. The sample of species studied is very diverse, including herbs, weeds, vines, shrubs and trees. Data are discussed regarding previous genome size estimates of closely related species or genera, if any, their chromosome number, growth form or invasive behaviour. The present research contributes approximately $1.5 \%$ new values for previously unreported angiosperm families, being the current coverage around $55 \%$ of angiosperm families, according to the Plant DNA C-Values Database.
\end{abstract}

Key words: angiosperm families; C-value; eudicots; flow cytometry; genome size; nuclear DNA amounts.

\section{Resumen}

Primeras estimaciones del tamaño del genoma para algunas familias y géneros eudicotiledóneos.- La diversidad del tamaño del genoma en angiospermas es muy amplia, siendo el valor más elevado aproximadamente unas 2400 veces superior al más pequeño. Sin embargo, cerca del $45 \%$ de las familias no presentan ni una sola estimación, por lo que el rango real podría ser ampliado. Para contribuir a completar la representación de familias y géneros de angiospermas, este estudio contribuye con valores C para 19 especies de 16 familias de eudicoticotiledóneas, incluyendo los primeros valores para 6 familias, 14 géneros y 17 especies. La muestra estudiada es muy diversa, e incluye hierbas, malezas, enredaderas, arbustos y árboles. Se discuten los resultados en función de estimaciones previas del tamaño del genoma de especies o géneros estrechamente relacionados, del número de cromosomas, la forma de crecimiento o el comportamiento invasor de las especies analizadas. El presente estudio contribuye aproximadamente en un 1,5\% de nuevos valores para familias de angiospermas no estudiadas previamente, de las que actualmente existe información para el $55 \%$, según la base de datos de valores $\mathrm{C}$ en plantas.

Palabras clave: cantidades de ADN nuclear; citometría de flujo; eudicotiledóneas; familias de angiospermas; tamaño del genoma; valor C. 


\section{INTRODUCTION}

The C-Value, i.e. the amount of DNA in the unreplicated genome of an individual (Swift, 1950) is an essential biological character, considered constant (hence the " $\mathrm{C}$ " of the term) for a particular species. Genome size is of interest in many research fields and relationships between $\mathrm{C}$-Values and cytological traits, ecology, life cycle or distribution, among others, have been discussed in hundreds of scientific works, most of them from the last two decades (Ohri et al., 2004; Ohri 2005; Leitch et al., 2010).

Understanding the variation of nuclear DNA amounts between plant species is an essential step toward a better knowledge of their evolution and diversification. Genome size in angiosperms varies 2400-fold, ranging from the carnivorous plant Genlisea margaretae Hutch. (Lentibulariaceae) with $1 \mathrm{C}=0.0648 \mathrm{pg}$ of DNA (Greilhuber et al., 2006; Chase et al., 2009) to the monocot Paris japonica (Franch. \& Sav.) Franch. (Melanthiaceae, $1 \mathrm{C}=152.23 \mathrm{pg}$; Pellicer et al., 2010). This huge variation has interested many researchers, and it is usually attributed to changes in the proportion of non-coding DNA such as repetitive sequences, transposable elements or due to the extent of genome duplication processes - polyploidization (Leitch \& Hanson, 2002). This large angiosperm genome size range is also contrasting with the limited 16-fold of the gymnosperms or the narrow 12-fold variation of bryophytes (Plant DNA C-values database).

According to Leitch et al. (1998) and Soltis et al. (2003), genome sizes can be assigned to a series of distinct categories: "very small" (1C-Values $\leq 1.4 \mathrm{pg})$, "small" ( $>1.4$ to $\leq 3.5 \mathrm{pg})$, "intermediate" $(>3.5$ to $<14.0 \mathrm{pg})$, "large" ( $\geq 14$ to $<35 \mathrm{pg})$ and "very large" $(\geq 35 \mathrm{pg}$ ). Nevertheless, the vast majority of angiosperm species assessed up to now present "small" or "very small" values, and "very large" ones are exceptional. Regarding small genome sizes, Leitch et al. (2005), superimposing the available C-Value data onto an angiosperm phylogeny, concluded that the ancestral genome size of all angiosperms was reconstructed as "very small" as well as that of most major clades within angiosperms.

\section{Obtaining C-Value data}

Given the apparent interest that data on nuclear DNA amounts raises, particularly in plant research, efforts have been done to compile C-Values, either in the form of species lists (Marie \& Brown, 1993; Bennett \& Leitch, 1995, 1997; Bennett et al., 2000; Zonneveld et al. 2005; Siljak-Yakovlev et al., 2010) or databases. Several databases are currently freely available on the internet. They pool published plant genome size estimations (the "Plant DNA C-Value Database", Bennett \& Leitch, 2010), focused on flow cytometric measurements of C-Values (Loureiro et al., 2010) or on a particular plant family (the upcoming "Genome Size in the Asteraceae Database", Garnatje et al., 2010). Also, scientific meetings (first and second Plant Genome Size Workshop and Discussion Meetings, held at the Royal Botanic Gardens, Kew, in 1997 and 2003 respectively) and the workshop "Genome size: a research discipline in development" (XVII International Botanical Congress, 2005, Vienna) have been useful in identifying major gaps and recommending priorities in genome size assessments. One of these targets was to produce first C-Values for an additional 1\% of angiosperm species, achieving with this at least $75 \%$ familial representation by 2009 (Bennett \& Leitch, 2005), although updates in this sense are yet to come. Following these guidelines, a subsequent paper (Hanson et al., 2005) contributed with first data for 20 previously unrepresented families, increasing angiosperm familial representation to $55 \%$.

The present paper addresses some of the key recommendations exposed at the last discussion meetings concerning angiosperm families and genera representation, by increasing the number of families reported and complementing other scarcely previously reported ones, according to available databases and other published research.

\section{MATERIALS AND METHODS}

\section{Plant material}

Table 1 lists the 19 species from different families and genera not or scarcely represented in the Plant DNA C-Values Database (Bennett $\&$ Leitch, 2010), together with their geographic origin, growth form, life cycle, chromosome number (when available), genome size with standard deviation and calibration standard used for flow cytometric assessments. Plants were obtained 


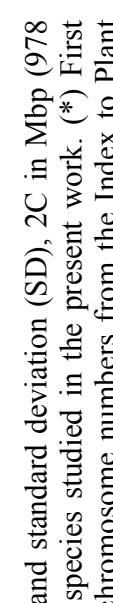

에응

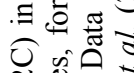

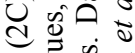

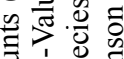

పे क⿺ 一兀

矿芯志

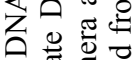

ธี

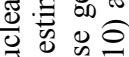

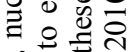

穵它

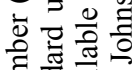

灵家

焉品

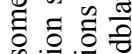

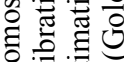

긍 ज्ञ

额

J.

$\dddot{\exists} . \Xi$

U一

สิ)

घ8

.00 त

ठิ

40

호욜

政这

ฮึ

站卷是

क⿺辶万ᄋ

$\mathbb{S}_{0}$ on 0

츨

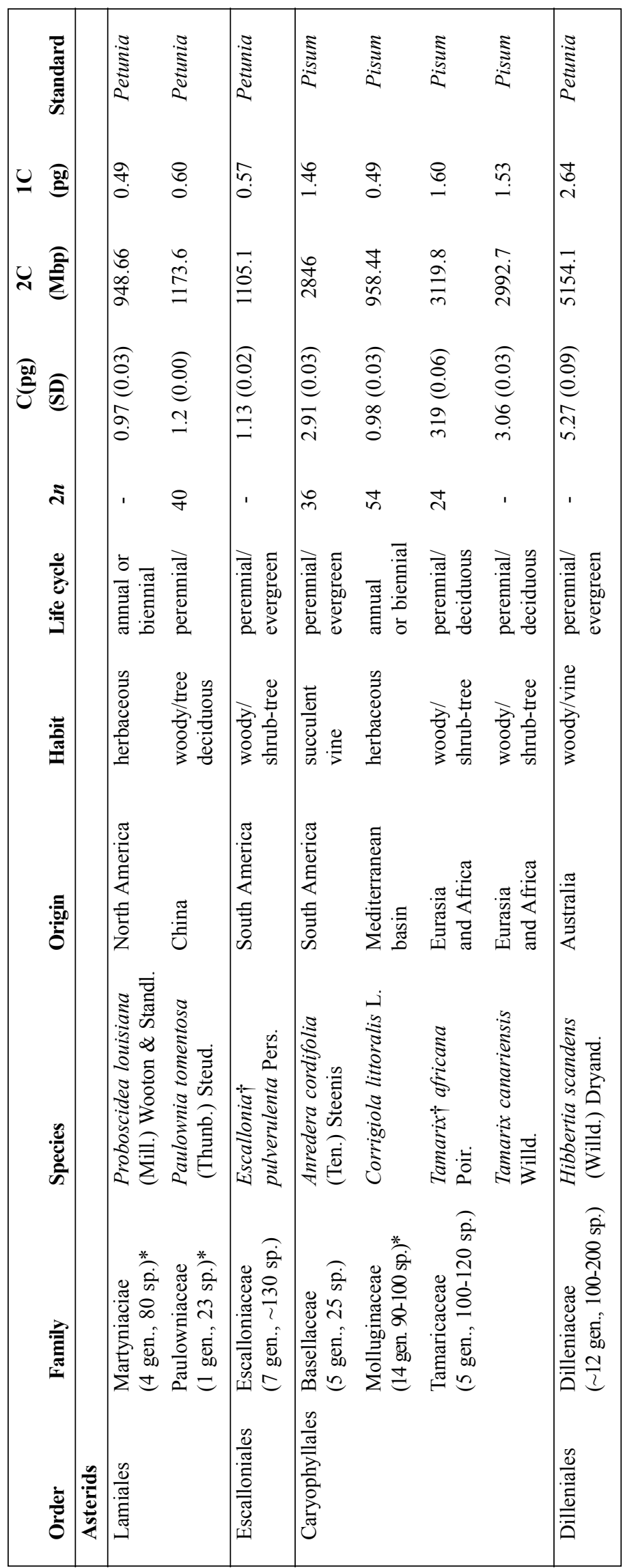




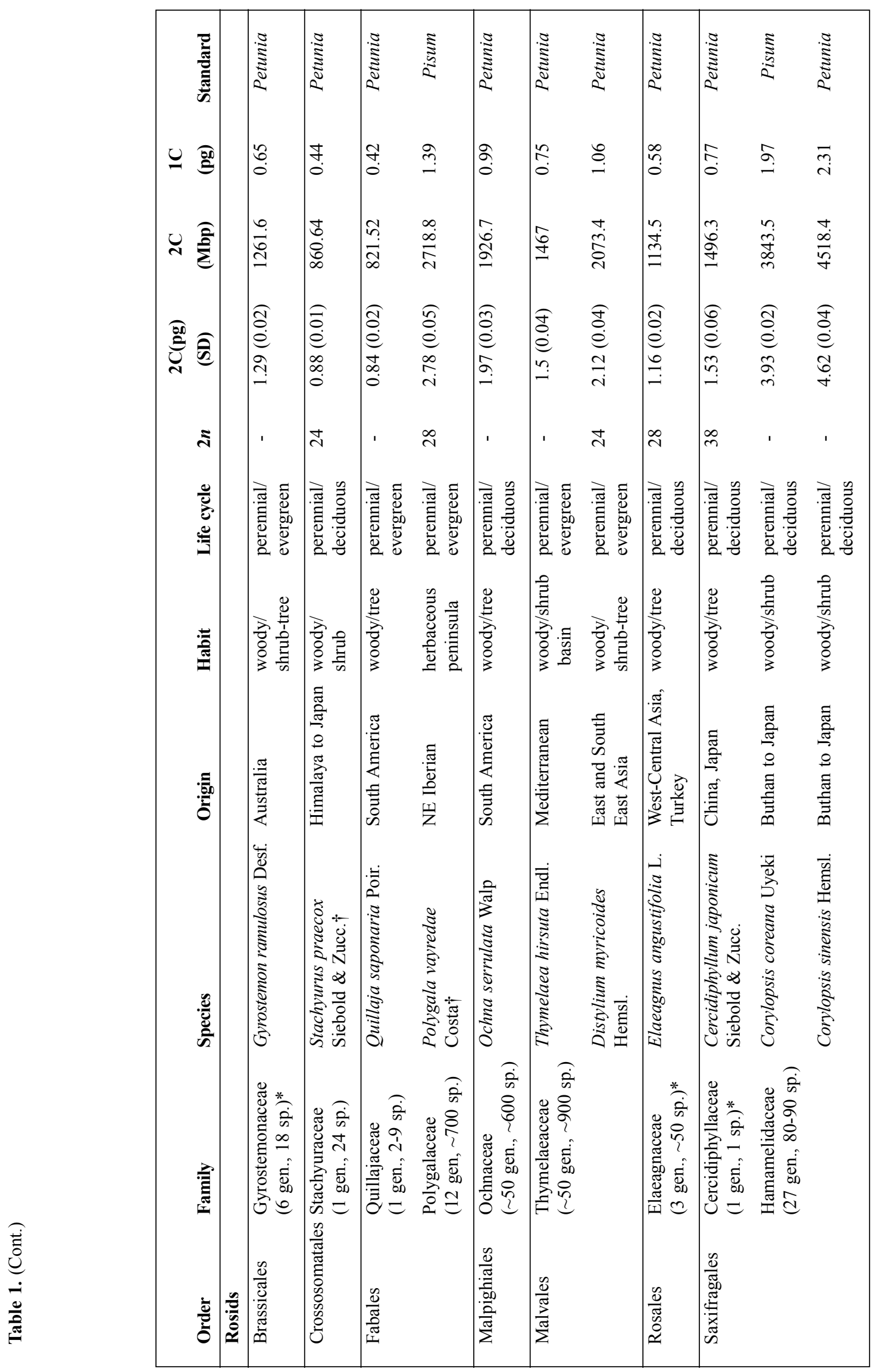


from the Jardi Botànic de Barcelona or through Index Seminum of different international institutions, and some of them were grown at the greenhouses of the Institut Botànic de Barcelona and of the Facultat de Farmàcia de la Universitat de Barcelona. Young leaves used for flow cytometry assays were taken from plants cultivated in pots. Seeds of Pisum sativum L. 'Express Long' and an adult Petunia hybrida Vilm. 'PxPc6', both used as internal standards for flow cytometric measurements (Marie \& Brown, 1993), were obtained from the Institut des Sciences du Végétal (CNRS, Gif-sur-Yvette, France).

The selected sample is very diverse (Fig. 1), comprising from annuals to perennials, from herbs to trees, of a wide geographical range and with a variety of uses. There are plants with economic importance, as some with medicinal properties (Thymelaea hirsuta Endl., Quillaja saponaria Poir., or Corrigiola littoralis L.), others used as ornamental (the deciduous trees Cercidiphyllum japonicum Siebold \& Zucc., Paulownia tomentosa (Thunb.) Steud. and Tamarix L. species), and some ornamentals exhibiting an invasive behaviour (such as Anredera cordifolia (Ten.) Steenis, Ochna serrulata Walp. and the previously mentioned Paulownia).

\section{Flow cytometry}

The DNA 2C values of the tested species were estimated using flow cytometry. Young healthy leaf tissue of five individuals for each studied species was chopped in $600 \mu 1$ of Galbraith's isolation buffer (Galbraith et al., 1983) with a razor blade, together with the chosen internal standard and supplemented with $100 \mathrm{lg}$ Eml)1 ribonuclease A (RNase A; Boehringer, Meylan, France).; two samples per individual were independently extracted. The suspension of nuclei in the isolation buffer was filtered through a nylon mesh with a pore size of $70 \mu \mathrm{m}$ and stained for 20 min with $36 \mu 1$ of propidium iodide $1 \mathrm{mg} / \mathrm{ml}$ (Sigma-Aldrich Química, Alcobendas, Madrid) to a final concentration of $60 \mu \mathrm{g} / \mathrm{ml}$. Tubes were kept on ice during staining and then left at room temperature until measurement. The flow cytometer used was an Epics XL (Coulter Corporation, Hialeah, Florida, USA.), at the Serveis Cientificotècnics of the Universitat de Barcelona. More details about the method followed are described in Garcia et al. (2008).

\section{RESULTS AND DISCUSSION}

The present study contributes data for 19 species from 16 eudicot families. Genome size estimations are new for families Cercidiphyllaceae, Elaeagnaceae, Gyrostemonaceae, Martyniaceae, Molluginaceae and Paulowniaceae. Besides, genome sizes for 14 new genera and 17 new species are here reported for the first time. Table 1 lists nuclear DNA amounts in the 19 taxa studied. Values range approximately 6-fold: the lowest $1 \mathrm{C}$ value in the plants studied is for the tree Quillaja saponaria $(0.42 \mathrm{pg})$ and the highest for the creeper Hibbertia scandens (Willd.) Dryand. (2.64 pg). Most genome sizes of the species analysed (65\%) fall within the category "very small", and the remaining are considered "small" (following Leitch et al., 1998 and Soltis et al., 2003). Although, as mentioned, genome size range across angiosperms is very large, a histogram based on Plant DNA C-Values data extracted from the Plant DNA C-Values Database (Bennett \& Leitch, 2010) and including last results from Pellicer et al. (2010) shows the distribution of angiosperm $1 \mathrm{C}$ values (Fig. 2), revealing that most species have very small genomes (the histogram is strongly skewed to left). However, while $99.5 \%$ of all eudicots have genomes smaller than $25 \mathrm{pg}$, there is a $10 \%$ of monocots with genomes larger than this cipher (Leitch et al., 2010). Lineages with such large genomes are phylogenetically restricted not only to the monocots but also to the Santalales, pointing that very large genomes have independently evolved different times during the evolution of angiosperms (Leitch et al., 1998; Soltis et al., 2003).

\section{Species and genera previously reported}

Data obtained for the species Polygala vayredae Costa is consistent with the $1 \mathrm{C}=1.35 \mathrm{pg}$ previously reported by Castro et al. (2007) also with flow cytometry. There is only another species from this genus (and from this family, according to the Plant DNA C-Values Database, Bennett \& Leitch, 2010), P. calcarea F. W. Schultz, whose genome size has been assessed twice independently: $1 \mathrm{C}=0.49 \mathrm{pg}$ (Castro et al., 2007) and 1C $=0.43$ pg (Hanson et al., 2005). Chromosome numbers for these species are $2 n=28$ and $2 n=c a$. 30, respectively.

The ornamental shrub Stachyurus praecox Siebold \& Zucc. was assessed for genome size and 

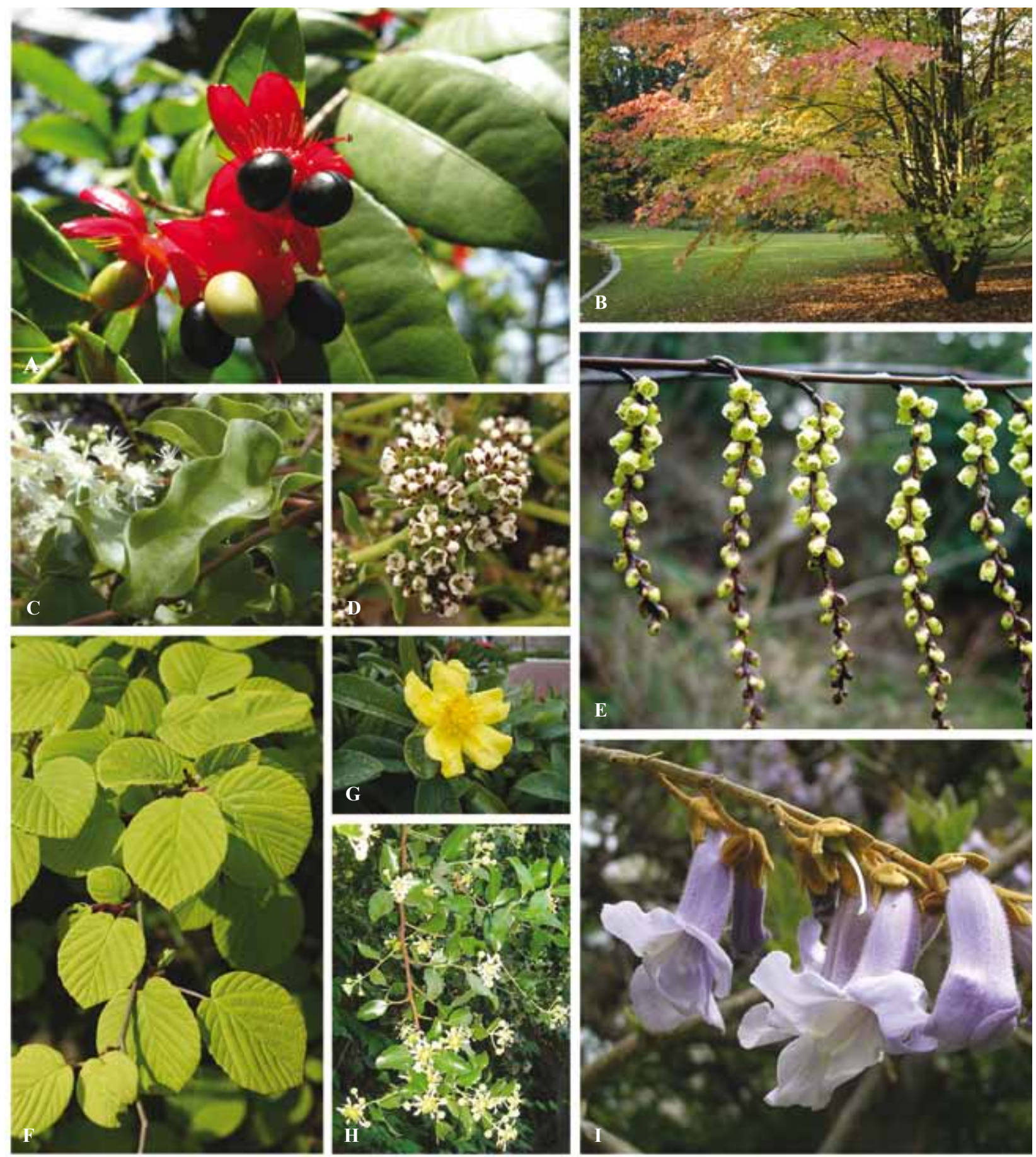

Figure 1. Some of the species here studied: (A), Ochna serrulata; (B), Cercidiphyllum japonicum [picture by Jean-Pol Grandmont]; (C), Anredera cordifolia; (D), Corrigiola littoralis; (E), Stachyurus praecox [picture from home-and-garden. webshots.com]; (F), Corylopsis gotoana [picture by Krzysztof Zianerk]; (G), Hibbertia scandens; (H), Quillaja saponaria; (I), Paulownia tomentosa. All pictures except E taken from Wikimedia commons under the terms of GNU free documentation license (different versions) or under the Creative Commons Attribution-Share Alike license (different versions).

chromosome number for the first time by Hanson et al. (2005), who obtained $1 \mathrm{C}=0.35 \mathrm{pg}$ and $2 n=24$. Our result $(1 \mathrm{C}=0.44 \mathrm{pg})$ is approximately $25 \%$ lar- ger than theirs. This difference exceeds the accepted range of variation within a species, as discussed in Garcia et al. (2006). Both genome size estimations 
have been performed with different techniques (Hanson's with Feulgen microdensitometry and the present one with flow cytometry), and using different calibration standards (Vigna radiata (L.) R.Wilczek 'Berken', 2C $=1.06$ pg, vs. Petunia hybrida, $2 \mathrm{C}=2.85 \mathrm{pg}$ ), which could explain partly the difference between the measurements, although ideally they should be comparable.

The tamarisks had yet been represented, as for genome size data, by the species Tamarix tetrandra Szov. ex Bunge with a 1C value of $1.55 \mathrm{pg}$ (also using flow cytometry with propidium iodide stain; Zonneveld et al., 2005), a value which is also consistent with our present data. To our knowledge, this is also the only genus of family Tamaricaceae for which genome size has been previously assessed.

The evergreen shrub Escallonia pulverulenta Pers. is similar to the tamarisks in that it is a species tolerant to maritime exposure. There are two previous genome size estimations for other Escallonia species: E. rubra Pers. presents a value fairly similar to the present one $(1 \mathrm{C}=0.42 \mathrm{pg})$ albeit being obtained by Feulgen microdensitometry (Hanson et al., 2005) whereas E. langleyensis Vilm. \& Bois C-Value $(1 \mathrm{C}=6.15 \mathrm{pg}$, Zonneveld et $a l ., 2005)$ is much larger. It is likely that the latter is a polyploid but we cannot ascertain this in the absence of chromosome counts.

\section{Chromosome number and genome size}

The scarce available published data on chromosome numbers for the studied species gathered from the Index to Plant Chromosome Numbers (IPCN) from the Missouri Botanical Garden (Goldblatt \& Johnson, 2010) and from Hanson et al. (2005) does not allow raising a pattern related to genome size. However, it is to note that the species with more chromosomes are among those with smaller genomes. Although the sample of plants here studied is very heterogeneous and the data incomplete, this coincides with previous findings reporting relatively small genome sizes in species with high chromosome numbers (Murray et al., 2005; Leitch et al., 2010). However, an analysis carried out on angiosperm $1 \mathrm{C}$ values and chromosome numbers (using the Plant DNA $\mathrm{C}$-Values database) did not reveal any significant relationship between both datasets.

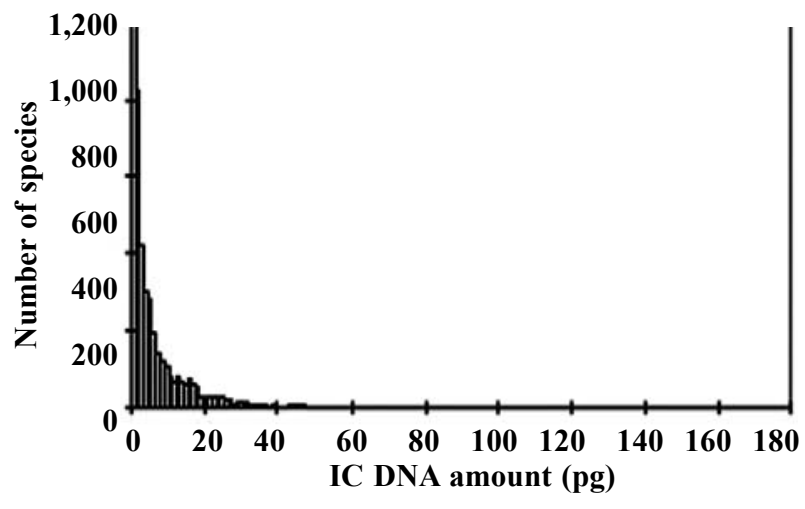

Figure 2. Histogram showing the distribution of angiosperm $1 \mathrm{C}$ values [data from the Plant DNA C-Values Database (Bennett \& Leitch, 2010) including last results from Pellicer et al. (2010)].

\section{Genome sizes in trees}

Trees are a polyphyletic assemblage (including angiosperm and gymnosperm species) but they share key characters such as great size, height and longevity features that explain their ecological success (Petit \& Hampe, 2006). Tree species are found in all eudicot orders except in Geraniales and Gunnerales (Groover, 2005). All the tree species of our sample (Table 1) present invariably very small $\mathrm{C}$-Values (from $1 \mathrm{C}=0.42 \mathrm{pg}$ to $1 \mathrm{C}=0.99 \mathrm{pg}$ ), and also those considered as shrub-trees rank very low. This is consistent with low genome sizes found in most angiosperm trees (see some examples of such low amounts in Table 2), despite widespread paleopolyploidy and high chromosome numbers with respect to herbaceous angiosperms (Mehra, 1976; Ehrendorfer, 1982; Morawetz, 1986); in this sense Levin \& Wilson (1976) had estimated that tree genera have a mean basic chromosome number of 13.1 whereas it is only 9.3 in herbaceous plants.

A study about the consequences on genome size of climate and growth form in plants (Ohri, 2005) concluded that, in an angiosperm sample, woody growth was characterized by a significantly smaller genome size compared with the herbaceous growth form. It was also found that woody monocots had larger genome sizes than eudicot ones, and that woody gymnosperms presented even larger genome sizes. Although the author did not find a direct explanation for the association of small genome 
Table 2. 1C genome sizes for some angiosperm tree species. Data are extracted from the Plant DNA C-Values Database (Bennett \& Leitch, 2010). Note low C-Values for most of this representative sample.

\begin{tabular}{|lc|}
\hline Tree species & 1C value (pg) \\
\hline Acer pseudoplatanus L. & 1.18 \\
Aesculus hippocastanum L. & 0.60 \\
Alnus glutinosa (L.) Gaertn. & 0.55 \\
Betula L. sp. & $0.20-0.75$ \\
Ceratonia siliqua L. & 0.57 \\
Crataegus crus -galli L. & 1.35 \\
Eucalyptus globulus Labill. & 0.58 \\
Fagus sylvatica L. & 0.56 \\
Fraxinus excelsior Boiss. & 0.98 \\
Malus communis Desf. & 2.25 \\
Prunus L. sp. & $0.28-3.65$ \\
Quercus L. sp. & $0.5-1.00$ \\
Rhamnus cathartica Pall. & 1.33 \\
Salix L. sp. & $0.35-0.86$ \\
Ulmus glabra Huds. & 1.08 \\
\hline
\end{tabular}

size with woody habit, others claim that the woody growth implies constraints on maximum nuclear size of the small cambial cells forming wood fibres (Stebbins, 1950; Khoshoo, 1962). In the same line, Beaulieu et al. (2010) demonstrated that the tempo of genome size evolution was strongly influenced by growth form, suggesting that life history alone could impose constraints in the evolution of genome size; however they did not find a consistent pattern of woody species having smaller genome sizes in genera consisting of both woody and herbaceous species. Nevertheless, angiosperm trees are reported to have large effective population sizes (Petit \& Hampe, 2006), which would make selection more efficient at removing deleterious mutations or excess DNA (Lynch, 2007), and this might explain reduced genome sizes.

We have also compared genome sizes of deciduous $v s$. evergreen woody eudicots of our sample, even considering that our sample is not representative. Values differed approximately 4-fold both in deciduous and evergreen plants, but the analysis showed a non-significant difference between both categories $(\mathrm{P}=0.3466)$. As the present one, a previous study did not find a significant difference between genome sizes of deciduous and evergreen woody dicots, using a sample of 773 woody species (Ohri, 2005).

\section{Genome size in weeds and in carnivorous plants}

Plants exhibiting an invasive or weedy behaviour have in general small genome sizes (Bennett et al., 1998; Knight \& Ackerly, 2002). Three of the studied species, Anredera cordifolia, Pawlonia tomentosa and Proboscidea louisiana (Mill.) Wooton \& Standl., have been recorded as weeds and have small or very small genome sizes. Bennett et al. (1998) found significant differences between weeds and other species, being the invasive plants the ones with significantly smaller DNA amounts (also found in Kubešová et al., 2010); they also demonstrated that the probability of a species being a weed felt significantly with increasing genome size. The finding that invasive species have smaller genomes than non-invasive ones is also significant in subgenus Pinus (Grotkopp et al., 2004). Garcia et al. (2008) proved the same pattern for the species of genus Artemisia listed as weeds in the US invasive plants list (USDA Natural resources conservation service: invasive and noxious weeds, 2010) which always presented significantly lower C-Values as compared with the non-invasive Artemisia. Questions are still open regarding how (and why) selection operates against high nuclear DNA amounts in groups as different as weeds and trees.

The weed Proboscidea louisiana is also a carnivorous (murderous) plant, as the slime that it secrets on its leaves is the trap of the insects that approach it. Genome size of carnivorous plants has also been studied given the particularity of such plants. A search in the Plant DNA C-Values shows that most carnivorous plants are defined as having very small genome sizes, as ours with $1 \mathrm{C}=0.49 \mathrm{pg}$. As mentioned in the introduction, the plant with the smallest genome size so far reported is carnivorous. Exceptions are, however, Sarracenia flava L. $(1 \mathrm{C}=4.34 \mathrm{pg})$ and Drosophyllum lusitanicum (L.) Link $(1 \mathrm{C}=15 \mathrm{pg})$, also carnivorous and having intermediate and large genome sizes. Hanson et al. (2001) speculated that plants inhabiting nutrient-poor environments, such as carnivorous, might have smaller genome sizes by necessity; nevertheless, given the results for Sarracenia and Drosophyllum, it is evident that small or very small genome sizes are not always an essential adaptation to restricted conditions (Hanson et al., 2005). 


\section{Progress towards completing family representation}

This study follows the Angiosperm Phylogeny Group, APG III (2009) which recognizes 415 families. However, the number of families can vary with time, as new ones are created while some are divided or merged, based on new molecular or morphological data. These changes complicate establishing how many families are there, what is the proportion represented in the Plant DNA C-Values Database and therefore which new percentages actually contribute papers like the present one. Since 2001, the Royal Botanic Gardens, Kew, has been targeting families for which no previous C-Value data had been published, with the purpose of achieving $75 \%$ familial coverage by 2009 (Hanson et al., 2005), as stated. At present, genome size data is listed in the Plant DNA C-Values Database for 55\% of angiosperm families; the present research increases this representation in $1.45 \%$, awaiting for the next update of this database, whose release (including new data for around 1600 angiosperm species) is expected for 2010 (Plant DNA C-values database, 2010).

\section{ACKNOWLEDGEMENTS}

The authors thank M. Veny (Institut Botànic de Barcelona) for taking care of the plant collections and helping in the identification of some specimens. Dr. S. C. Brown and O. Catrice (Institut des Sciences du Vegétal, CNRS) are acknowledged for supplying both calibration standards. Dr. J. Comas, Dr. R. Álvarez and Ch. González (Universitat de Barcelona) provided technical support in flow cytometry. This research was supported by DGICYT (Spanish Government; projects CGL2007-64839-C02-01 and 02/ BOS and CGL2010-22234-C02-01 and 02/BOS) and Generalitat de Catalunya (project 2009SGR439). S. G. received a JAE-Doc contract from the CSIC, O. H. a MICINN postdoctoral grant from the Spanish Government and I. S.-J. and D. V. FPU predoctoral grants from the Spanish Government as well.

\section{REFERENCES}

APG (Angiosperm Phylogeny Group) 2009. An update of the angiosperm phylogeny group classification for the orders and families of flowering plants: APG III. Bot. J. Linn. Soc. 161: 105-121.

Beaulieu, J. M., Smith, J. A. \& Leitch, I. J. 2010. On the tempo of genome size evolution in angiosperms. Journal of Botany, vol. 2010, article ID 989152, 8 pages, doi:10.1155/2010/989152.

Bennett, M. D. \& Leitch, I. J. 1995. Nuclear DNA amounts in angiosperms. Ann. Bot. (Oxford) 76: 113-176.

Bennett, M. D. \& Leitch, I. J. 1997. Nuclear DNA amounts in angiosperms - 583 new estimates. Ann. Bot. (Oxford) 80: 169-196.

Bennett, M. D., Leitch, I. J. \& Hanson, L. 1998. DNA amounts in two samples of angiosperm weeds. Ann. Bot. (Oxford) 82, Suppl. A: 121-134.

Bennett, M. D., Bhandol, P. \& Leitch, I. J. 2000. Nuclear DNA amounts in angiosperms and their modern uses -807 new estimates. Ann. Bot. (Oxford) 86: 859-909.

Bennett, M. D. \& Leitch I. J. 2005. Nuclear DNA amounts in angiosperms: progress, problems and prospects. Ann. Bot. (Oxford) 95: 45-90.

Bennett, M. D. \& Leitch, I. J. 2010. Plant DNA C-Values Database. Retrieved Set 28, 2010, from http://www.kew. org/cvalues/

Castro, S., Loureiro, J., Rodriguez, E., Silveira, P., Navarro, L. \& Santos, C. 2007. Evaluation of polysomaty and estimation of genome size in Polygala vayredae and P. calcarea using flow cytometry. Pl. Sci. (Elsevier) 172: 1131-1137.

Chase, M. W., Christenhusz, M. J. M., Sanders. D. \& Fay, M. F. 2009. Murderous plants: Victorian Gothic, Darwin and modern insights into vegetable carnivory. Bot. J. Linn. Soc. 161: 329-356.

Doležel, J., Bartoš, J., Voglmayr, H. \& Greilhuber, J. 2003. Nuclear DNA content and genome size of trout and human. Cytometry 51: 127-128.

Ehrendorfer, F. 1982. Speciation patterns in woody angiosperms of tropical origin. In: Barigozzi, C. (Ed.), Mechanisms of Speciation. Alan R. Liss., New York: 479-509.

Galbraith, D. W., Harkins, K. R., Maddox, J. M., Ayres, N. M., Sharma, D. P. \& Firoozabady, E. 1983. Rapid flow cytometric analysis of the cell cycle in intact plant tissues. Science 220: 1049-1055.

Garcia, S., Garnatje, T., Twibell, J. D. \& Vallès, J. 2006. Genome size variation in the Artemisia arborescens complex (Asteraceae, Anthemideae) and its cultivars. Genome 49: 244-053.

Garcia, S., Canela, M. A., Garnatje, T., McArthur, E. D. M., Pellicer, J., Sanderson, S. C. \& Vallès, J. 2008. Evolutionary and ecological implications of genome size in the North American endemic sagebrushes and allies (Artemisia, Asteraceae). Biol. J. Linn. Soc. 94: 631-649.

Garnatje T., Canela M. Á., Garcia S., Hidalgo O., Pellicer J., Sánchez-Jiménez I., Siljak-Yakovlev S., Vitales D. \& Vallès J. 2010. GSAD: a database on genome size of the family Asteraceae. Retrieved Set 30, 2010, from http://www. etnobiofic.cat/gsad/

Goldblatt, P. \& Johnson, D. E. (Eds.). 2010. Index to plant chromosome numbers. Missouri Botanical Garden, St. Louis. Retrieved Oct 7, 2010, from http://mobot.mobot. org/W3T/Search/ipcn.html

Greilhuber, J., Borsch, T., Müller, K., Worberg, A., Poremboski, S., \& Barthlott W. 2006. Smallest angiosperm genomes found in Lentibulariaceae with chromosomes of bacterial size. Pl. Biol. (Stuttgart) 8: 770-777.

Groover, A. T. 2005. What genes make a tree a tree? Trends Pl. Sci. 10: 210-214.

Grotkopp, E., Rejmanek, M., Sanderson, M. J. \& Rost, T. L. 2004. Evolution of genome size in pines (Pinus) and its life-history correlates: supertree analyses. Evolution 58: 1705-1729.

Hanson, L., Boyd, A., Johnson, M. A. T. \& Bennett, M. D. 
2005. First nuclear DNA C-Values for 18 eudicot families. Ann. Bot. (Oxford) 96: 1315-1320.

Hanson, L., McMahon, K. A., Johnson, M. A. T. \& Bennett, M. D. 2001. First nuclear DNA C-Values for 25 angiosperm families. Ann. Bot. (Oxford) 87: 251-258.

Khoshoo, T. N. 1962. Cytogenetical evolution in gymnospermskaryotype. Proceedings of the summer school Darjeeling. Government of India, Darjeeling: 119-135.

Knight, C. A. \& Ackerly, D. D. 2002. Variation in nuclear DNA content across environmental gradients: a quantile regression analysis. Ecol. Letters 5: 66-76.

Kubešová, M., Moravcová, L., Suda, J., Jarošíik, V. \& Pyšek, P. 2010. Naturalized plants have smaller genome size than their non-invading relatives: a flow cytometric analysis of the Czech alien flora. Preslia 81: 81-96.

Leitch, I. J., Beaulieu, J. M., Chase, M. W., Leitch, A. R. \& Fay, M. F. 2010. Genome size dynamics and evolution in monocots. Journal of Botany, vol. 2010, article ID 862516, 18 pages, doi 10.1155/2010/862516.

Leitch, I. J. \& Hanson, L. 2002. DNA C-Values in seven families fill phylogenetic gaps in the basal angiosperms. Bot. J. Linn. Soc. 140: 175-179.

Leitch, I. J., Chase M. W. \& Bennett M. D. 1998. Phylogenetic analysis of DNA C-Values provides evidence for a small ancestral genome size in flowering plants. Ann. Bot. (Oxford) 82: 85-94.

Leitch, I. J., Soltis, D. E., Soltis, P. S. \& Bennett, M. D. 2005. Evolution of DNA amounts across land plants (Embryophyta). Ann. Bot. (Oxford) 95: 207-217.

Levin, D. A. \& Wilson, A. C. 1976. Rates of evolution in seed plants: net increase in diversity of chromosome numbers and species numbers through time. Proc. Natl. Acad. Sci. U.S.A. 73: 2086-2090.

Loureiro, J., Rodriguez, E., Santos, C., Doležel, J. \& Suda, J. 2010. FLOWer: A Plant DNA Flow Cytometry Database. Retreived Sep 27, 2010, from http://flower.web.ua.pt/

Lynch, M. 2007. The origins of genome architercture. Sinauer Associates, Sunderland, Massachussets.
Marie, D. \& Brown, S. C. 1993. A cytometric exercise in plant DNA histograms, with $2 \mathrm{C}$ values for 70 species. Biol. Cell 78: 41-51.

Mehra, P. N. 1976. Cytology of Indian hardwoods. Sree Saraswaty Press. Ltd., Calcuta.

Morawetz, W. 1986. Remarks on karyological differentiation patterns in tropical woody plants. Pl. Syst. Evol. 152: 49-100.

Murray, B. G., De Lange, P. J. \& Ferguson, A. R. 2005. Nuclear DNA variation, chromosome numbers and polyploidy in the endemic and indigenous grass flora of New Zealand. Ann. Bot. (Oxford) 96: 1293-1305.

Ohri, D., Bhargava, A., \& Chatterjee, A. 2004. Nuclear DNA amounts in 112 species of tropical hardwoods - new estimates. Pl. Biol. (Stuttgart) 6: 551-561.

Ohri, D. 2005. Climate and growth form: the consequences for genome size in plants. Pl. Biol. (Stuttgart) 7: 449-458.

Pellicer, J., Fay, M. F. \& Leitch, I. J. 2010. The largest eukaryotic genome of them all? Bot. J. Linn. Soc. 164: 10-15.

Petit, R. J. \& Hampe, A. 2006. Some evolutionary consequences of being a tree. Annual Rev. Ecol. Evol. Syst. 37: 187-214.

Siljak-Yakovlev, S., Pustahija, F., Šolić, E. M., Bogunić, F., Muratović, E., Bašić, N., Catrice, O. \& Brown, S. C. 2010. Towards a genome size and chromosome number database of Balkan flora: C-Values in 343 taxa with novel values for 242. Adv. Sci. Lett. 3: 190-213.

Soltis, D. E., Soltis, P. S., Bennett, M. D. \& Leitch, I. J. 2003. Evolution of genome size in the angiosperms. Amer. J. Bot. 90: 1596-1603.

Stebbins, G. L. 1950. Variation and evolution in plants. Columbia University Press, New York.

Swift, H. H. 1950. The deoxyribose nucleic acid content of animal nuclei. Physiol. Zool. 23: 169-198.

USDA. 2010. Natural resources conservation service: invasive and noxious weeds. Retrieved Sep 20, 2010, from http:// plants.usda.gov/java/noxiousDriver

Zonneveld, B. J. M., Leitch, I. J. \& Bennett, M. D. 2005. First nuclear DNA amounts in more than 300 angiosperms. Ann. Bot. (Oxford) 96: 229-244. 